J. Product. \& Dev., 23(3): $789-805(2018)$

\title{
IMPACT OF ARABIC-SPRING ON COMPETITIVENESS OF ARAB STATES AGRICULTURAL EXPORTS TO EU MARKETS
}

\author{
Ibrahim Soliman and Halah E. Bassiony \\ Department of Agricultural Economics, Faculty of Agriculture, Zagazig \\ University, Zagazig, Egypt.
}

\section{ABSTRACT}

The Arab States trade (21 Countries) with the EU countries represents the largest proportion of their total trade with the whole world. It amounted to more than 60\% in 2011. Even though, the share of EU-markets in Arab States agricultural exports declined to $33 \%$ in 2018 but has remained the first market in terms of the agricultural exports value of the Arab countries. The revolutionary movements in five Arab countries (Tunisia, Egypt, Syria, Yemen and Libya) which was called Arab-Spring has had dramatic impacts on the economies of those countries. Thereof, this study targeted a comprehensive evaluation of sustainable competitive agricultural exports to EU-markets through application of a model of four components. The first was estimation of the annual revealed comparative index (RCA) over two periods (2000-2010) representing the Pre-Arab-Spring era and (2011-2017) representing the PostArab-Spring era. Second was selecting the exported food commodity groups, from Arab-Spring States to EU- markets that recognized values of RCA index above one along the years of each period. Secondly, a time-trend model was estimated for each identified food commodity group along each period to estimate the annual change in the RCA. Thirdly, the annual average of RCA index of the selected food groups was compared among the concerned countries. Fourthly, the study estimated a stability coefficient for each identified exported food group of each named five countries. Five sources of data were used to build up the trade flow matrix of 10 food commodity groups of the concerned countries.

As Libya agricultural exports has not passed any of the four applied criteria the analysis identified Fish (Tunisia and Yemen, vegetables and fruits (Egypt, Tunisia and Syria), sugar and Honey (Egypt and Syria) and tea, cocoa and spices (Syria). However, only Egypt and Tunisia showed sustainable competitiveness during the 
Post-Arb-Spring era, even though at less criteria than the Pre-ArabSpring era. The sustainable competitiveness of all commodity groups but vegetables and fruits showed a declining performance either before or after the Arab-Spring era.

The study underlined the importance of coordination and integration of the exports policies among the four identified Arab countries to raise their sustainable competitiveness in the European markets. As the four countries enjoy diversification in climate, water, soil resources and location advantages, they can establish joint venture projects for grading packing processing, storage and transportation network.

Key Words: Competitiveness, Revealed Comparative Advantage, Instability, Sustainability.

\section{INTRODUCTION}

Even though, the Arab States trade (21 Countries) with the EU countries still represents the largest proportion of their total trade with the whole world. It amounted to $32.7 \%$ in 2017 , such proportion has dropped significantly from 60\% in 2011, (Complied and calculated from: world integrated trade solution, 2017). The declaration of the free trade agreements and trade facilitation among those countries.

The entry of Arabic States in the new world order implied trade liberalization and the implementation of the principle of comparative advantage in the use of resources, which in turn supposed to lead to exports development, accelerate their economies' growth and increasing incomes of their citizen towards welfare, (Ali, 1999). However, it seems that the liberalization of foreign trade alone does not create competitiveness of a country as does not necessarily increase domestic supply, production and employment, (Soliman, 2000). The local economic growth and productivity are the corner stone in doing such job, as a resultant of efficient management of national resources, (Frankel and Romer, 1999). The practices have demonstrated many obstacles and difficulties that faced Arabic States which limited the growth of exports and consequently has slowed down the growth of income and consumption.

The health and environmental specifications of food commodities have generated barriers on the Arab states trade, which decreased the expected benefits of free trade, (Soliman, 1992). Notably, the WTO agreements implicitly, provided protection for the multinational companies, which expanded to become transnational companies. 
Therefrom, it has being difficult to distinguish their geographical identity or nationality. They have practiced significant control on the global market, either on food and agricultural commodities trade inputs production, or on technology transfer. Such control stemmed from being giant companies with capabilities to practice monopolistic behavior on the world trade relationships, consequently, they have violated the rights of small farmers, particularly in the Arab countries (Soliman,1999).

Arab countries have experienced a deficit in the balance of trade of food and agricultural commodities and goods, which led them away from the area of competitiveness. While the agricultural imports of Arab countries accounted about $24.5 \%$ in total Arab States merchandise imports, the contribution of agricultural exports in total merchandize exports has not exceeded 9.6\%, (Compiled and calculated from: AOAD, 2016). Thereof, the agricultural exports covered only 19.1 percent of its imports in 2017, (Compiled and calculated from: AOAD, 2016). The inability of local production to provide enough surplus for exportation of agricultural commodities has limited the capacity of Arab countries to penetrate the world markets, even though, the Arabic States possess about 72.03 million hectares of cultivated land. In addition, the Arab countries hold high proportion of irrigated land reaching about 23.1 percent of the total cultivated land, while the world average is about 17.4\%, (Soliman, 2007). Notably, low productivity was behind production deficit. Whereas, the Arab countries possess $4.2 \%$ of the world agricultural land the agricultural output is around $3 \%$ of the world's agricultural output, as the productivity per hectare of agricultural land has not exceeded $77.6 \%$ of the world productivity. Low productivity reflects the technological gap between Arabic agricultural systems and world system, (Soliman, 2007).

However, since 2011 the Arab states have faced dramatic political changes. Revolutionary movements have occurred in several Arab countries "Tunisia, Egypt, Syria, Libya and Yemen". Such changes have had drastic socio-economic draw backs on all Arab States. Such date has given a political title "Arabic Spring Era". Therefore, this study has considered the impact of such era (2011-2017) on the Arab States' agricultural exports competitiveness in the major importing market of the Arab States agricultural commodities which, is the EU-market, in comparison with agricultural exports to the same market before "the Arabic Spring Era", i.e. during the period (2000-2010). The Arab Spring revolutionary movements had occurred in 2011 in five Arab States. Tunisia, Egypt, Syria, Libya and Yemen.

Accordingly, the objective was proceeded via following a model that 
combined two criteria for evaluating the competitiveness of the agricultural exports of the five Arab-Spring States to EU markets. First, estimating the index of the comparative advantage (RCA) of the selected countries 'in agricultural exports to EU markets. Secondly, If the RCA continued at a value above one all the time series, the study would estimate quantitatively the sustainability (stability) of such comparative advantage index Such two criteria (RCA and Stability Coefficient) were applied for 10 agricultural commodity groups for the Ara countries that have shown high potential competitiveness in the European markets, along each of the two concerned periods, which are before the Arabic Spring Era (2000-2010) and after the Arabic Spring Era (2011-2017).

\section{ANALYTICAL PROCEDURES}

\section{Measuring Revealed Comparative Advantage Index (RCA)}

Equation (1) was used to calculate the revealed comparative advantage index (RCA), of Agricultural Exports of Arab States to EU (Soliman and Bassiony, 2012). When the value of this index surpasses a value of one indicates that such country has comparative advantage in exporting a certain commodity to a given market and vice versa. The larger the value of RCA, the higher is the magnitude of the comparative advantage.

Where:

$$
\mathrm{RCAij}=\mathrm{R}[(\mathrm{xiJ} / \mathrm{xit}) /(\mathrm{xnj} / \mathrm{xnt})]
$$

RCAij $=$ Revealed Comparative Advantage Index of Exports of State I and Food Group j, X = Refer to value of exports $(\$ 1,000), \mathrm{i}=$ Refers to an Arabic State, $\mathrm{j}=$ Refers to a commodity group, $\mathrm{t}=$ Indicates the total commodity groups, $\mathrm{n}=$ Refers to the EU markets, $\mathrm{X} \mathrm{iJ}=$ Value of exports of merchandise group j from the State i (\$1000), to the selected markets, $\mathrm{X}_{\mathrm{it}}=$ Total value of exports of all commodity groups except the specific group $\mathrm{j}$ from the State $\mathrm{i}$, to the selected markets, $\mathrm{X} \mathrm{nj}=$ World exports of commodity group $\mathrm{j}$ except the exports of the commodity group $\mathrm{j}$ from the State $\mathrm{i}$ to the selected markets, $\mathrm{x}_{\mathrm{nt}}=$ Total value of exports of all commodity groups (except the exports of group j) in the world minus all commodity groups in state $i$ (except the export group $j$ ) to selected markets.

Therefore, any one of the five Arab-States that performed RCA>1 of a certain food commodity group to EU market along one of the two concerned periods was considered as a country that has competitiveness in the EU market within that period. However, the sufficient condition of 
such competitiveness was the relative magnitude of the stability of the RCA value above one along that period (2000-2010).

\section{Measuring the Coefficient of Stability in RCA Value}

The export of a food commodity from any of the five Arab state to EU markets that showed continuous value of RCA $>1$ was introduced to the measurement of the stability coefficient of the time trend of the RCA values along the concerned time period. The stability was estimated using the time trend equation (equation 2). Thereafter, counting for the percentage of the average absolute value of deviations of the estimated RCA values ( $\hat{Y}$ ) from their actual values (y) and applying (equation 3), it was possible to derive the coefficient of instability in the RCA (Akpaeti et al., 2014). However, the positive view to such assessment towards competitiveness implied to measure the coefficient of stability, rather than instability, for RCA values, which was derived from (Equation 4). The high stability coefficient implies the success of the export policy of that country for a certain food commodity group that performed a sustainable (continuous) RCA values $>1$ over a long time series.

$$
\hat{Y}_{\mathrm{t}} \mathrm{i}=\alpha+\beta \mathrm{T} i+\zeta \mathrm{ij}
$$

Estimated Instability Coefficient of $(y)=[(|y t-\hat{y} t|) /(\hat{y} t)] \times 100$

$($ Estimated stability coefficient $=[1-($ instability coefficient $)]$

Where:

$\mathrm{Yt}=$ the actual values of RCA in the year $\mathrm{t}, \alpha=$ The estimated intercept of the regression equation (It is the average value of RCA at the base year $(t=0), \beta=$ Estimated Average annual change in the RCA value, $T_{i}$ $=$ the Time element as digital values, where: $\mathrm{i}=0,1,2 \ldots, \mathrm{t}_{1}$ and $\mathrm{t}_{2}$ for the two concerned periods successively, $\zeta \mathrm{ij}=$ the estimated residual (Error) variable, $\hat{y t}=$ Estimated value of RCA in the year $\mathrm{t}$ from equation 9.

\section{DATA SOURCES}

The study relied on the following data sources:(I) Statistical Data Base of the Food and Agriculture Organization of the United Nations (FAO, 2016), , (2) Statistical Data Base of the World Bank, (World Bank, 2013), (3) Statistical Data Base of Arab Organization for Agricultural Development (AOAD, 2014), and (5) The United Nations Statistical Data Matrices of Trade Flows of Exported Commodities, (UN, 2017), for the period (2000-2017). These sources provided data of the annual export value of the food commodity groups from the Arab states to the countries of the European Union. moreover, all trade data used in the research. The 
EU markets were treated aggregately in this study, as they follow almost the same agricultural foreign trade policies.

The study concerned with 10 food commodity groups classified according to the standard international trade classification (STIC). It is a commercial classification that serves several purposes, customs, foreign trade policies, and commodity standards used in world trade. Therefore, it generates successive versions which are adjusted according to the dynamic changes in the structure of the world trade over time as a result of new or improved goods to reflect the pattern of international trade. It is more useful classification for economic analysis. The targeted 10 commodity groups were reclassified under sub-codes (01-09, where . the code of zero (00), was a code for the aggregate food and live animals' commodities.

\section{RESULTS AND DISCUSSION}

For a comprehensive and simplified analysis of results, the study classified this section into sections not by countries but by the exported food commodities group to the EU-markets which performed sustainable competitiveness. Under each of these sections, comparison of the competitiveness and sustainability of exporting policy of the Arab-spring countries performance and between the two concerned periods were presented

The analysis of the Sustainable Competitions of Agricultural Exports from Arab Spring Countries to EU showed three sets of those countries. The first set included only Libya which, as entirely an oil country, that showed either before or after Arab Spring era either zero, absent data or negligible values on exporting agricultural products to EU. Thereof, it was a conclusive result about this country. The main reason was lack of adequate and continuous water supply. The second set included Yemen and Syria which performed sustainable competitiveness of agricultural exports of some food commodity groups to EU markets, only before Arab Spring Era and failed to record agricultural exports data after 2010. The third set included Egypt and Tunisia, where both performed sustainable competitiveness of their agricultural exports of some food commodity groups to EU markets either before or after Arab Spring Era.

\section{Vegetables and Fruits:}

During the decade before the Arab-Spring Tunisia, Syria and Egypt had shown a competitiveness in exporting vegetables and fruits to EU-markets . Table (1) and Figure (1) showed that the revealed comparative advantage index (RCA) was larger than one which, had lasted above the level of one all 
over the concerned period (2000-2010). However, Egypt showed the highest significant annual growth rate in RCA value of about 0.93 units above one, followed by Syria that showed a significant annual growth rate in RCA of about 0.32 units above one. Tunisia had the lowest annual growth in RCA value of about 0.19 above one, but statistically significant.

Table (2) showed that Egypt was not only of the highest growth rate of the RCA index before the Arb-Spring period, but it also had the highest average value of RCA of about 5.46. Syria came at the second rank with respect to the average RCA value for exporting vegetables and fruits to EUmarkets. Even though, Tunisia enjoyed the advantage of nearer location to EU markets than Egypt and the advantage of preferable trade partner with EU, (Thabet, 2011), it had an average RCA value of about one-third of the comparable value of Egypt, i.e. 2.6.

With respect to the magnitude of stability of such competitiveness, Table (2) showed that Tunisia had the highest level of stability of RCA over the period (2000- 2010) of about 92\& followed Syria (78\%) and them Egypt $(60 \%)$. Such results showed that the exports policy of Tunisia to Eu-market was more stable than the other two countries and the Syrian policy was more stable than the Egyptian exports policy during that period. Therefore, Although Tunisia, Syria and Egypt had been characterized by competitiveness in the exports of vegetables and fruits to the EU market before the Arb-Spring Era, Egypt had the highest level of competitiveness while Tunisia had the highest stable policy in this concern.

After the onset of the Arab-Spring in 2011, the annual growth rate of RCA shown by Egyptian exports of vegetables and fruits to EU-markets increased significantly much to reach about 2.87 units above one, followed by Tunisian Exports of about 0.19 units above one along the period (20112017). However, the sever internal fighting in Syria had almost stopped exportation of vegetables and fruits to EU-markets.

The average RCA coefficient of Tunisia exports increased to 3.7 and the average RCA coefficient of Egypt increased to 24.21, with respect to exporting vegetables and fruits to EU markets while the Arab-Spring period resulted in complete deterioration of such competitiveness in exporting vegetables and fruits to Eu markets from Syria.

With respect to stability of competitiveness, it increased for Tunisia and Egypt to reach $94 \%$ and $86 \%$, respectively. Therefore, only Egypt Tunisian and Egyptian economy which had not only resisted during the Arab-Spring period with respect to exporting vegetables and fruits to EU-markets but the performance criteria of such policy shoed more sustainable competitiveness. 
Table (1). Estimated Time-Trend of RCA Index for Agricultural Exports Before and After 2011.

\begin{tabular}{|c|c|c|c|c|c|c|c|}
\hline \multirow{2}{*}{ Country } & \multirow{2}{*}{$\begin{array}{l}\text { Commodit } \\
\text { y Group }\end{array}$} & Time-Trend Equation & $R^{2}$ & $\mathbf{F}$ & Time-Trend Equation & $R^{2}$ & $\mathbf{F}$ \\
\hline & & \multicolumn{3}{|c|}{$2000-2010$} & \multicolumn{3}{|c|}{ 2011-2017 } \\
\hline \multirow{2}{*}{ Tunisia } & Fish & $\begin{array}{c}\hat{y}=6.51-0.26 x \\
(0.33)(0.05)\end{array}$ & 0.699 & $20.9 *$ & $\begin{array}{c}\hat{y}=5.07-0.19 x \\
(0.34)(0.09)\end{array}$ & 0.432 & $3.81 *$ \\
\hline & $\begin{array}{l}\text { Vegetable } \\
\text { s, Fruits }\end{array}$ & $\begin{array}{c}\hat{y}=1.75+0.19 x \\
(0.24)(0.04)\end{array}$ & 0.716 & $22.7 *$ & $\begin{array}{c}\hat{y}=4.22+0.19 x \\
(0.23)(0.06)\end{array}$ & 0.636 & $8.74 *$ \\
\hline \multirow{3}{*}{ Egypt } & $\begin{array}{l}\text { Vegetable } \\
\text { s, Fruits }\end{array}$ & $\begin{array}{c}\hat{y}=1.20+0.93 x \\
(2.07)(0.35)\end{array}$ & 0.439 & $7.04 *$ & $\begin{array}{c}\hat{y}=15.99+2.87 x \\
(3.64)(1.01)\end{array}$ & 0.618 & $8.10^{*}$ \\
\hline & $\begin{array}{l}\text { Sugar, } \\
\text { Honey }\end{array}$ & $\begin{array}{c}\hat{y}=4.54-0.35 x \\
(0.76)(0.13)\end{array}$ & 0.451 & $7.39 *$ & $\begin{array}{c}\hat{y}=1.11-0.6 x \\
(0.16)(0.04)\end{array}$ & 0.244 & $1.62^{\text {n.s. }}$ \\
\hline & Grains & $\begin{array}{c}\hat{y}=2.30-0.17 x \\
(0.30)(0.05)\end{array}$ & 0.570 & $11.95^{*}$ & $\begin{array}{c}\hat{y}=0.24-0.02 x \\
(0.07)(0.02)\end{array}$ & 0.130 & $0.75^{\mathrm{ns.}}$ \\
\hline \multirow{3}{*}{ Syrian } & $\begin{array}{l}\text { Vegetable } \\
\text { s, Fruits } \\
\end{array}$ & $\begin{array}{c}\hat{y}=0.85+0.32 x \\
(0.57)(0.09)\end{array}$ & 0.592 & $11.60 *$ & n.a & - & - \\
\hline & $\begin{array}{l}\text { Sugar, } \\
\text { Honey }\end{array}$ & $\begin{array}{c}\hat{y}=2.26-0.07 x \\
(0.50)(0.08)\end{array}$ & 0.079 & $0.775^{\mathrm{n}}$ & n.a & - & - \\
\hline & $\begin{array}{l}\text { Tea/cocoa } \\
\text { / spices }\end{array}$ & $\begin{aligned} \hat{y}= & 13.28-1.38 x \\
& (3.55)(0.75)\end{aligned}$ & 0.423 & $5.86^{*}$ & n.a & - & - \\
\hline Yemen & Fish & $\begin{array}{c}\hat{y}=408.6-13.5 x \\
(117.4)(19.8)\end{array}$ & 0.049 & $0.462^{\text {n. }}$ & n.a & - & - \\
\hline
\end{tabular}

Source: Compiled and Calculated from: WITS (World Integrated Trade Solutions) https://wits.worldbank.org/ and equation (1).

n.a $=$ Not available data due to political and social conflicts and/or insignificant values.

Values between parenthesis are the SE of the estimated parameter.

$(*)=$ Significant at significance level $(\alpha=0.05)$ and n.s. $=$ Not statistically significant at $(\alpha=0.05)$.

Table (2). Table of Estimated Competitiveness Criteria.

\begin{tabular}{|l|l|c|c|c|c|}
\hline \multirow{4}{*}{ Country } & \multirow{2}{*}{ Commodity Group } & \multicolumn{2}{|c|}{$\begin{array}{c}\text { Before Arab-Spring } \\
\text { (2000-2010) }\end{array}$} & \multicolumn{2}{|c|}{$\begin{array}{c}\text { After Arab-Spring } \\
\text { (2011-2017) }\end{array}$} \\
\cline { 3 - 6 } & & $\begin{array}{c}\text { Aver. } \\
\text { of } \\
\text { RCA }\end{array}$ & $\begin{array}{c}\text { Stability } \\
\text { Coefficient }\end{array}$ & $\begin{array}{c}\text { Aver. } \\
\text { of } \\
\text { RCA }\end{array}$ & $\begin{array}{c}\text { Stability } \\
\text { Coefficient }\end{array}$ \\
\hline \multirow{3}{*}{ Tunisia } & Fish & 5.2 & 0.92 & 4.5 & 0.92 \\
\cline { 2 - 6 } & Vegetables, Fruits & 2.7 & 0.90 & 3.7 & 0.94 \\
\hline \multirow{3}{*}{ Egypt } & Vegetables, Fruits & 6.63 & 0.60 & 24.21 & 0.86 \\
\cline { 2 - 6 } & Sugar, Honey & 2.8 & 0.69 & 0.94 & 0.79 \\
\cline { 2 - 6 } & Grains & 1.44 & 0.68 & 0.18 & 0.56 \\
\hline & Vegetables, Fruits & 2.87 & 0.78 & n.a. & n.a. \\
\cline { 2 - 6 } & Sugar, Honey & 1.89 & 0.63 & n.a. & n.a. \\
\cline { 2 - 6 } & Tea, Cocoa, Spices & 5.51 & 0.59 & n.a. & n.a. \\
\hline Yemen & Fish & 340.06 & 0.51 & 341.1 & n.a. \\
\hline
\end{tabular}

Source: Compiled and calculated from Tables (1) and Equations (3-4).

$\mathrm{n} . \mathrm{a}=$ Not available data due to political and social conflicts and/or insignificant values. 
Figure (1). Revealed Comparative Advantage (RCA) of vegetables \& fruits group.

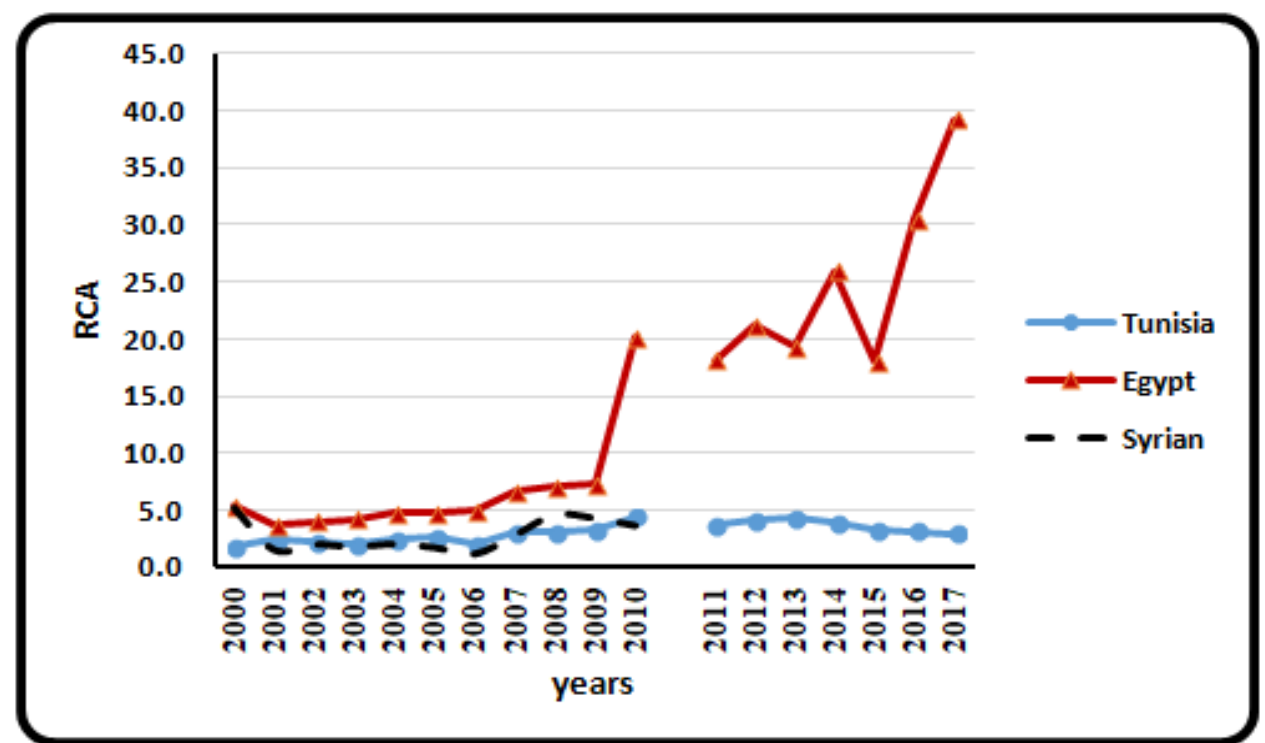

Source: Table (1).

Figure (2). Revealed Comparative Advantage (RCA) of Fish group.

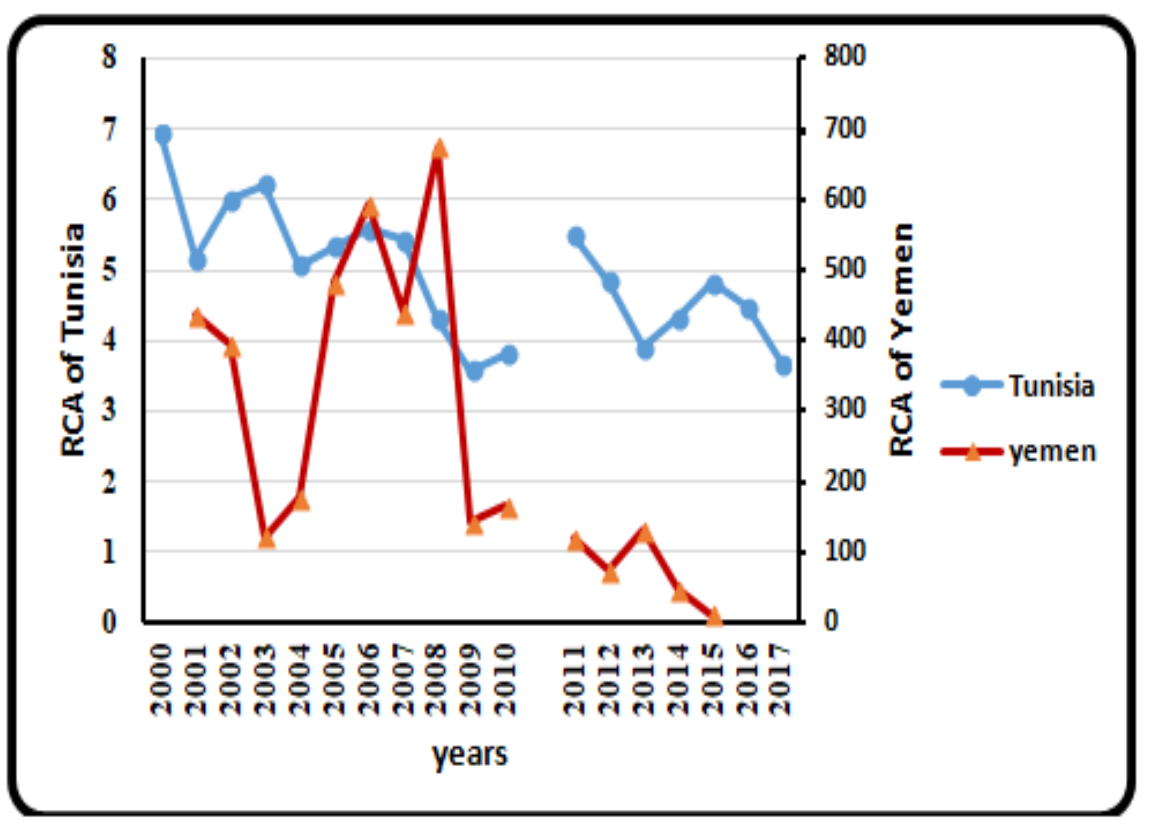

Source: Table (1). 


\section{Grains:}

The exports competitiveness of grain commodity group of Egypt to EU markets was deteriorating during the period before the Arab-Spring, particularly the years (2008-2010). Such performance was due to the Egyptian policies with respect to rice as the most important exports of this food commodity group. the distortions in Egyptian rice export policy over that period were behind the deterioration of the value of RCA, in particular, during the years (2008-2010). The rice exports were banned by the government (Ministry of Commerce, 2008) and by a fee that was levied on broken-rice-grains exports at a rate of 300 EGP per ton, (Ministry of Trade, 2009). In addition, the rain fall fluctuation in the main competitive rice exporting countries (China, Philippines, India, and Pakistan) caused fluctuations in the rice global supply between abundance and shortage which, was another major reason affecting Egypt's exports of rice, (Soliman and Gaber, 1997). Therefrom, there was a significant annual decrease in the RCA value by -0.17 units, (Table 1 and Figure 5).

The average value of RCA associated with grains exports of Egypt to EU reached 1.44 during the decade before 25th of January revolution in 2011, (Table 2). However, Egypt has lost the competitive advantage of exporting grains to EU-markets, during the post-Arab Spring period, not only as a result of the negative effects of the revolution of 25 January 2011 on the Egyptian economy, but also because rice as the main export crop in that group was banned by a taxation policy barrier as mentioned above. The average RCA index was declined much below one to reach 0.18 for the post Arb-Spring period, with a decrease in the stability coefficient from $68 \%$ before Arab-Spring period to 56\% after Arab-Spring period, (Table, $2)$. If the probable high risk in the Egyptian water resources supply due to the implementation program of filling the Ethiopian's "Al Nahda" High Dam in few years has become real, Egypt exports of rice would vanish, due to water scarcity constraint.

\section{Sugar and Honey:}

From Table (1), two Arb-Spring states showed relatively competitiveness in exporting sugar and honey commodity group to EUmarkets. They are Egypt and Syria, However, while Egypt produces sugarcane and sugar beet Syria produces only sugar beet. While the exports of sugar and honey products from Egypt to EU markets showed significant RCA $>1$ along the pre-Arab-Spring (2000-2011), but in one year only the RCA value of Egypt had dropped below one, Syria showed more fluctuated RCA index along that period, (Figure 3). 
During the pre-Arab-Spring period, Table (1) showed that there was a significant annual decrease in the RCA index value of Egyptian sugar exports to EU-markets by -0.35 units, while there was a significant annual decrease in Syrian sugar to EU-markets of about -0.07 units, i.e., there was a deterioration trend in this competitiveness, even before the Arab-Spring Era, (Fig. 3). However, the rate of deterioration was speeder in Egypt than Syria. The reasons behind such deterioration in Egypt's sugar exports to EUmarkets stemmed from the lack of appropriate policy at that time. Such policy in the period (2000-2010) based upon the utilization of the surplus designated capacity of its domestic refineries to refine apportion of imported raw sugar for re-exportation (62\% of exported value). The rest of exports value included Sugar confectionery (30\%) and Molasses (around 8\%), as most of produced molasses was used for processed feed mixes, (Compiled and calculated from FAO, 2016). In addition, towards rationality of limited water resources use and other reasons Egypt decreased the sugarcane area.

The average value of RCA of Egypt's exports of sugar to EU-markets was 2.8 with moderate stability coefficient around 69\% during (2000-2010), while such average of Syria was 1.89 with also a moderate stability coefficient of about $63 \%$ in exporting refined sugar from sugar-beet to EU markets

The sever domestic fights in Syria almost stopped exporting sugar to EU-markets during Post-Arab-Spring period, while the negative impacts of such period on Egyptian performance was relatively less. The annual decrease rate in RCA value was doubled to reach -0.6 units, but was not significant (Table 1), but the stability coefficient increased to $79 \%$ (Table 2). As the annual change rate in RCA was insignificant, thereof, the stability increased but the annual average value of RCA of about 0.94, (Table 2), showed that Egypt lost the competitiveness during the period (2011-2017).

\section{Fish:}

During the period before the Arab-Spring (2000-2010), Tunisia showed a declining sustainable competitiveness in fish products exports to EU markets. Table (1) and Figure (2) show that there was an annual significant decrease in the RCA index value of about -0.2 units. However, Yemen exports to EU-markets showed a faster decline in its competitiveness of exporting fish to EU-markets than Tunisia at an annual decrease rate in RCA value of -13.5 units, which did not match with the rich natural fisheries of Yemen sea shores. After the Arab-spring movement in Tunisia, the decline in the annual rate of change in the RCA 
Figure (3). Revealed Comparative Advantage (RCA) of Sugar \& Honey group

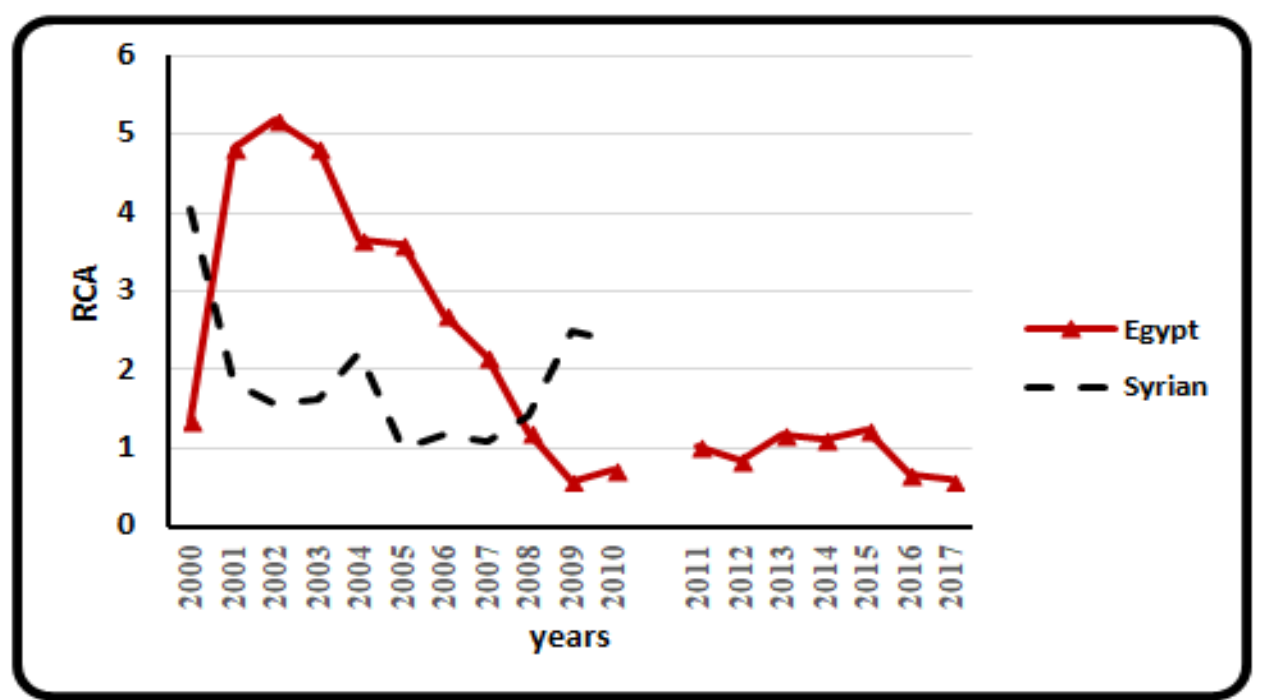

Source: Table (1).

Figure (4). Revealed Comparative Advantage (RCA) of Coffee/ tea/ cocoa/ spices group.

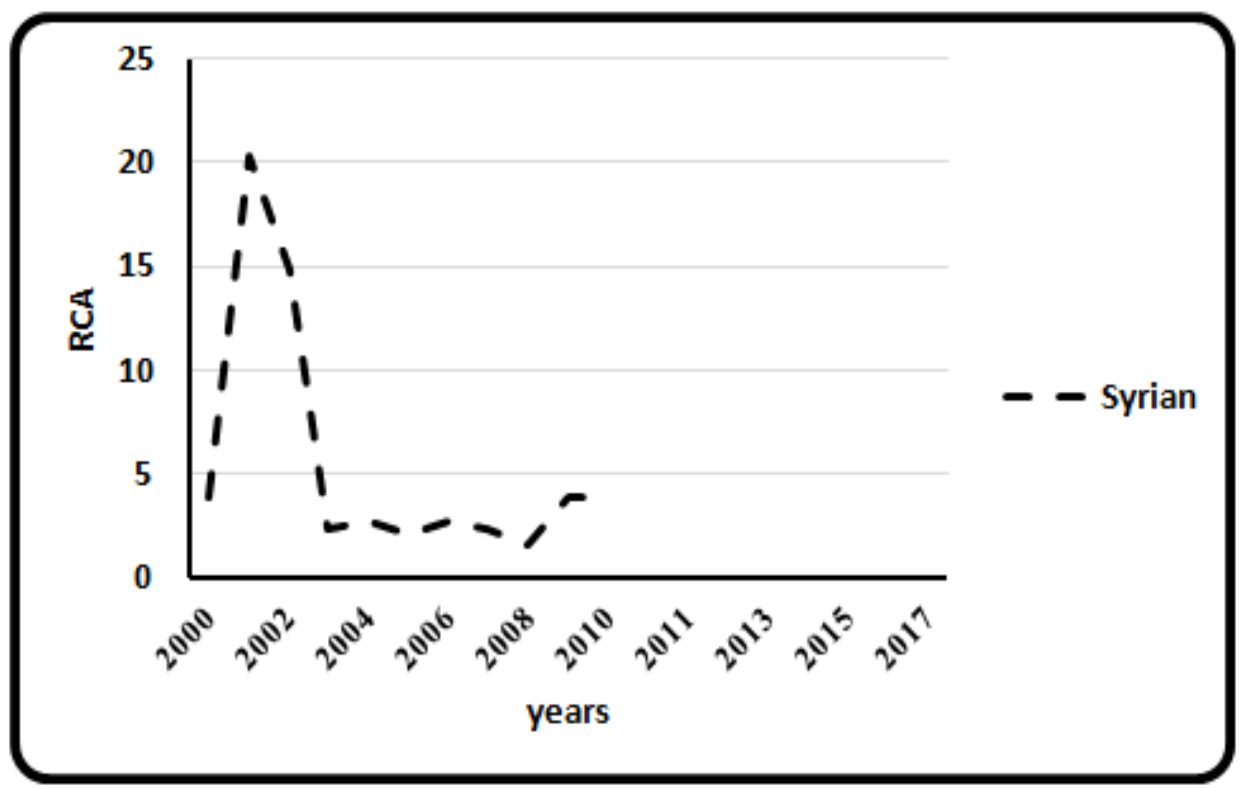

Source: Table (1). 
Figure (5). Revealed Comparative Advantage (RCA) of Grains.

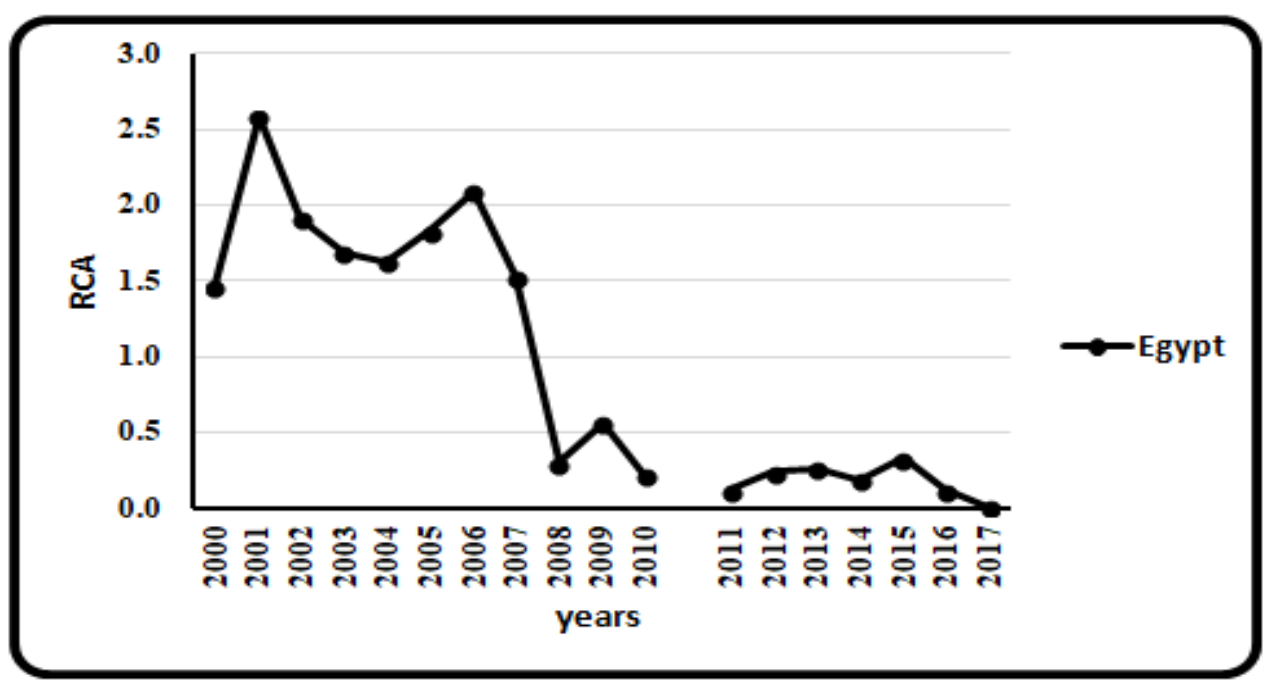

Source: Table (1).

index significantly decreased to -0.19 , i.e. the competitiveness of exporting fish to EU-markets had improved

From Table (2), the competitiveness of Tunisia's fish exports had performed high average value of RCA of about 5.17, with very high stability coefficient of about $92 \%$. However, Yemen during that period showed an outstanding competitiveness in Exporting fish to EU markets. The average RCA value index was around 340.06, but the stability coefficient was not high. i.e. about 51\%, (Table 2) and Figure (2). The higher competitiveness of fish export to EU from Yemen and less stability than Tunisia before the Arab-Spring era reflected the difference in the policies. Tunisia has stable contracting export policy to EU markets while Yemen used to rent the fishing area to international companies and frequently conflicts among the two partners raises to the surface.

\section{Tea, Cocoa and Spices:}

Syria had shown high competitiveness in exporting Tea, cocoa, spices to EU where, the average value of RCA was about 5.51 with a moderate stability coefficient of about 59\%, Figure (4), during the period (2000-2010), i.e. before the ARAB-Spring era. However, after the 2011 revolutionary movement such performance had completely disappeared. Such activity was reexporting sector via processing and packing of imported materials. Even though such relatively high RCA index value 
during the pre-Arab-Spring era, there was a significant declining annual rate in the RCA value of about -1,38 units during the period (2000-2010), (Table 1 and Figure 4).

\section{CONCLUSION AND RECOMMENDATIONS}

The study proposed that integration and consistency in trade policies of fruits and vegetables among "Egypt, Morocco, Tunisia and Sudan) in near future would promote their competitiveness in the EU markets. The four countries enjoy diversified climate, soil water resources and location advantages. Therefore, they can establish joint-venture projects for specific major essential marketing functions, particularly, grading, packing, processing, storages and transportation networks.

Notably, the Arab-Spring States, but Libya, are with significant agricultural resources. However, two of them (Syria and Yemen) are, currently, facing drastic economic, political and social troubles and conflicts that are expected to last in the forthcoming years. Therefore, those two countries have shown either zero value of RCA or not available data as indicators of the absence of agricultural exports competitiveness. Therefrom, Arab League should start from now to establish an Arabic Agricultural Fund that simulates the purposes and plans of the Care International Fund which was established after the 2nd World War to reestablish what the war had destroyed in the target European countries.

Syria and Egypt have a promising opportunity to integrate towards strengthen their competitiveness in exporting refined sugar via joint venture projects. The recommended strategy implied to allocate larger area for sugar-beet production in Syria associated with utilization of the full capacity of sugar refineries in Egypt. The ne harbors of Egypt to EU markets would add more competitiveness to such proposed integrated policies. Tunisia and Yemen showed high stable competitiveness in exporting fish to EU markets. Therefore, Integration among the two countries in this concern would raise their share in EU markets.

\section{REFERENCE}

Ali, Reham (1999). "Food Consumption in the Arabic States in the Light of Economic Developments" Regional and International Symposium on Analysis and Evaluation of National Policies and Programs Affecting the Consumption of Food Commodities, Cairo, Egypt. 
Akpaeti, A. J., Bassey, N. E., \& Okon, U. E. (2014). "Trend Evaluation of Agricultural Export Crops in Nigeria" International Journal of Food and Agricultural Economics (IJFAEC), 2(1).

AOAD (2014). Arab Organization for Agricultural Development .Yearbook of agricultural statistics Arabic ", vol. 32, 131-431.

FAO, UN (2014). "FAOSTAT" <www.fao.org >

Frankel, J. \& D. Romer (1999). "Does Trade Cause Growth?" American Economic Review Vol. 98.

Martinez, Gomez Victor \& Garcia, Jose-Maria (2012). "Assessing Trade Preferences for Moroccan Fruits and Vegetables with Preferential Entry Price" Sustainmed Project Working Paper NO. (Wp03d10 working paper 01 Morocco).

Ministry of Commerce (2008). "Ministerial Decree No. 258", Egyptian Facts Journal, No. 210, Cairo, Egypt.

Ministry of Trade (2009). "Imposing Levy On Broken Rice Grains Exports" Egyptian Facts, No. 165, $16^{\text {th }}$ of July, Cairo, Egypt.

Myers, I. B. \& McCauley, M. H. (1985). "A Manual of Index to the development and use of the Myers-Briggs type indicator", Palo Alto, CA: Consulting Psychologists Press, USA. Nowair, Tarek (2002), "The Government Role in Supporting Competitiveness: The Case of Egypt", A Series of Studies published by The Arab Planning Institute, Kuwait, P. 5.

OECD: (2000).Organization of Cooperation and Economic Development "Proceeding of the Annual Meeting".

Soliman, Ibrahim \& Bassiony, Halah (2012). "Egyptian Agricultural Exports Competitiveness" L'Egypte Contemporaine, Revue Scientifique Arbitrée Quart Annuel De La Société Egyptienne D' Economie Politique De Statistique Et De Législation, Caire, Vol. 104 No. 505 P. 5-40.

Soliman, Ibrahim (1992). "Environment and Food Challenges and Ambition", A Seventh Conference of Agricultural Economists from Agriculture in A Changing World, The Egyptian Association of Agricultural Economics, Agricultural Club, Doki, Giza, Egypt.

Soliman, Ibrahim (1999). "Concepts of Sustainable Development". The $8^{\text {th }}$ Conference of Agricultural Economists-Egyptian Society of Agricultural Economics, Doki, Giza, Egypt. 
Soliman, Ibrahim (2000). "Arab States Food Security and Global Economic Changes" The Eighth Conference of Agricultural Economists On: Agriculture and the challenges of the twenty-first century. Egyptian Association for Agricultural Economics.

Soliman, Ibrahim (2007). "Efficient Economic Resources: The Approach towards Agricultural Development in Arab States", Journal of Arab Economic Unity, Volume, 18, No. 34, pp.21-46

Soliman, Ibrahim \& Gaber, Mohammed (1997). "Consumption and Marketable Surplus of Rice and Corn under Economic Liberalization in Egypt", Zagazig Journal of Agricultural Research, Vol. 25, No. 6, P. 175-193, Issued by The Faculty of Agriculture, Zagazig University, Egypt.

Thabet, Boubaker (2011). "National Agri-food Policies in Tunisia: A Background Paper, "Work Package 2, Task TWP2T2, Sustainmed Project, FP7, EU.

UN, (2017). The United Nations Statistical Data Matrices of Trade Flows of Exported Commodities, The Statistics Division of the World Integrated Trade Solution (https://wits.worldbank.org/).

Wadeia, Mohammad Adnan, (2003). "Competitiveness and Measure,". Arab Planning Institute, Kuwait, Twenty-Fourth Edition, The Second Year, December, P. 5.

World Bank, (2013). "World Development Indicators", Washington D. C, USA.

$$
\begin{aligned}
& \text { أثز ثورات الربيع العربي على تنافسية الصادرات الزراعية للاول الإني } \\
& \text { العربية إلى أسواق الاتحاد الأوروبي }
\end{aligned}
$$

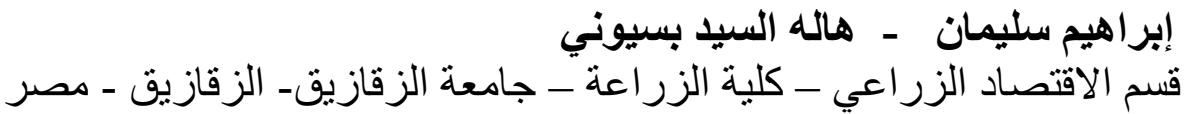

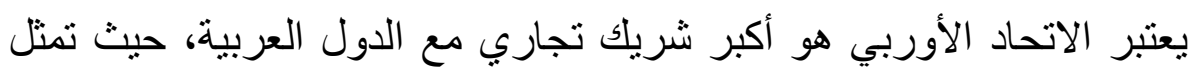

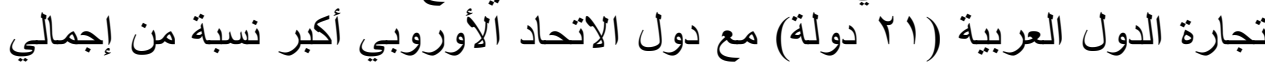

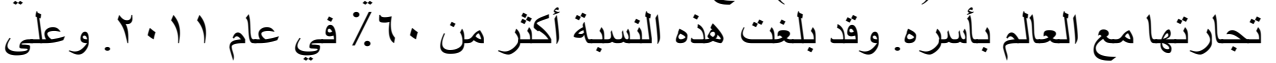

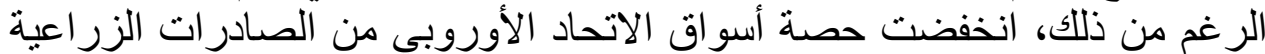

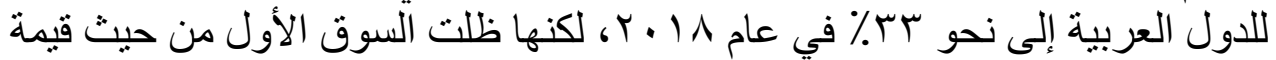

الصادر ات الزراعية للدول العربية. وكانت للحركات الثورية في خمس دول عربية 
هي : تونس ومصر وسوريا واليمن وليبيا، والتي أُطلق عليها اسم "ثورات الربيع

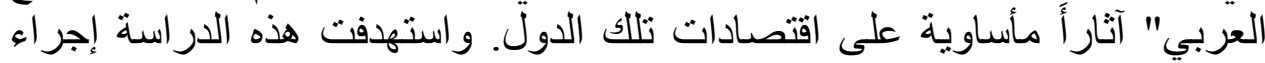

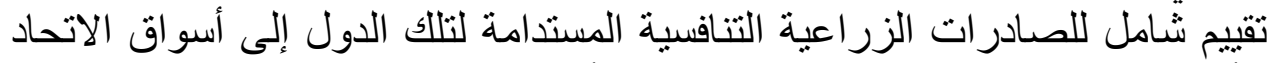

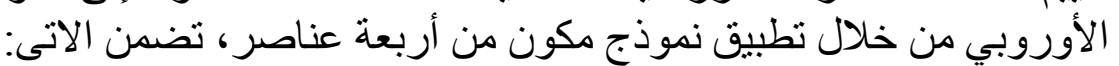

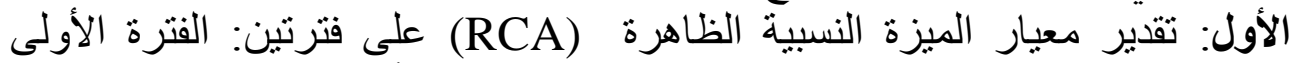

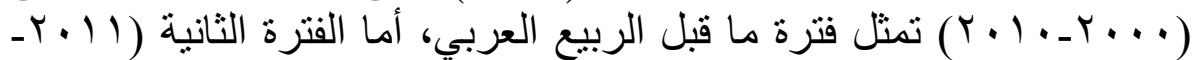
(Y. IV

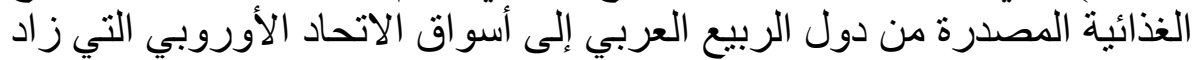

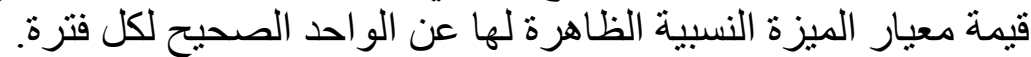

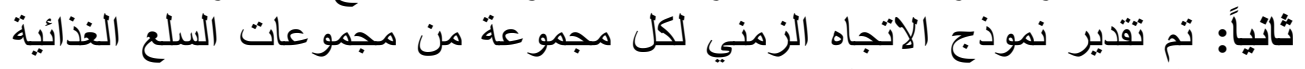
المحددة على امتداد كل فترة لتقدير التغير السنوي في معيار الميز الميزة النسبية الظاهرة . ثالثاً: تمث مقارنة المتوسط السنوي لمعيار الميزة النسبية الظاهرة لمجموعات الأغذية المختارة بين البلدان المعنة المعنية.

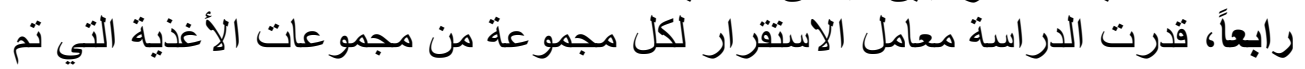

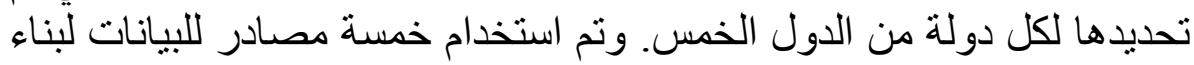
مصفوفة التدفق التجاري لعشر مجمو عات من السلع الغذائية في البلدان المعنية. ونظر اً لأن الصادرات الزراعية في ليبيا لم تتجاوز أي من المعايير الأربعة

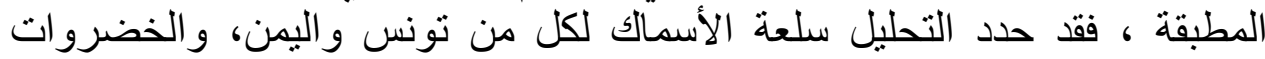

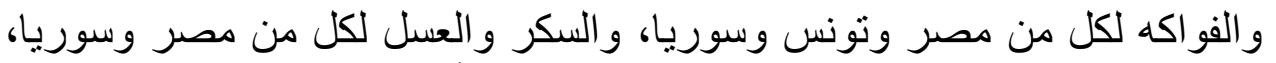

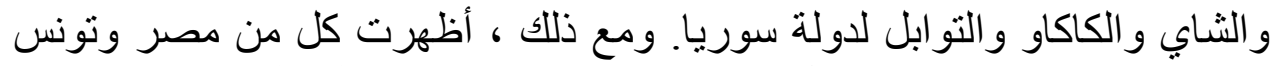

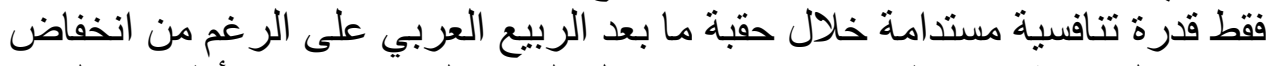

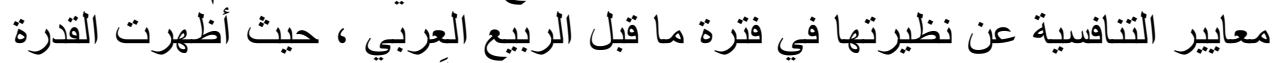

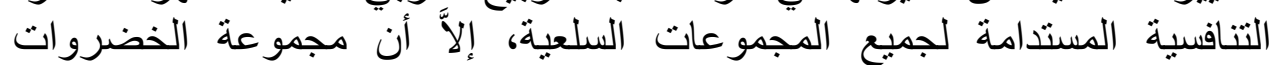

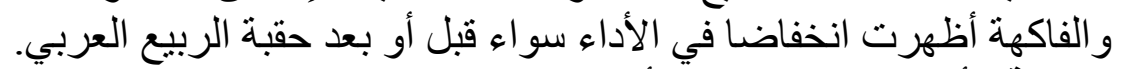

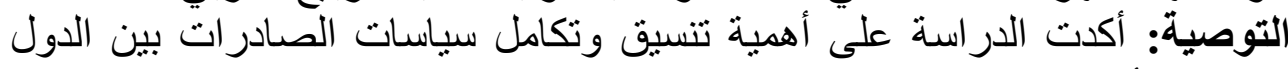

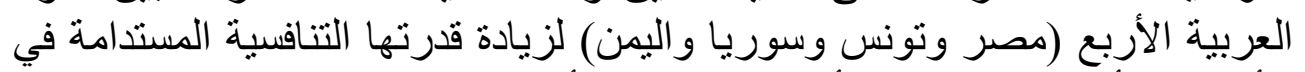

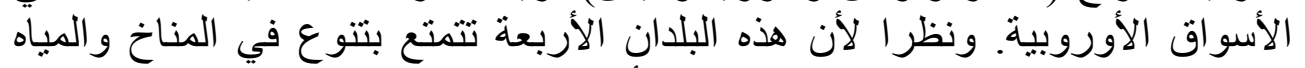

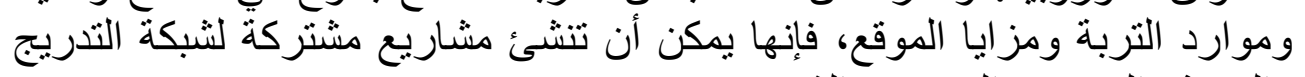

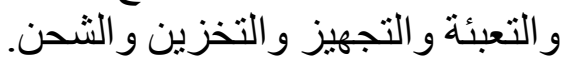

